\title{
Deteksi dan Evaluasi Keragaman Genetika Candidatus Liberibacter asiaticus sebagai Penyebab Penyakit Huanglongbing di Indonesia Berdasarkan Gen $\beta$-operon
}

\author{
Detection and Genetic Diversity Evaluation of Candidatus \\ Liberibacter asiaticus as the Causal Agent of Huanglongbing Disease \\ in Indonesia Based on $\beta$-operon Gene
}

\author{
Muhammad Rizal, Kikin Hamzah Mutaqin*, Gede Suastika \\ Institut Pertanian Bogor, Bogor 16680
}

\begin{abstract}
ABSTRAK
Huanglongbing atau di Indonesia dikenal sebagai citrus vein phloem degeneration (CVPD) adalah penyakit paling merusak pada jeruk di benua Asia, Afrika, dan Amerika. Penyebab penyakit huanglongbing di Indonesia telah dikonfirmasi disebabkan oleh Candidatus Liberibacter asiaticus (CLas) dan telah tersebar di Kalimantan Barat, Nusa Tenggara Timur, Bali, Yogyakarta, Jawa Tengah, dan Jawa Timur. Tujuan penelitian ialah mendeteksi $C$ Las sebagai penyebab penyakit huanglongbing pada beberapa lokasi pertanaman jeruk di Indonesia yang belum dan telah dilaporkan sebelumnya serta mengevaluasi kekerabatan dan keragaman genetika $C$ Las isolat Indonesia. DNA daun jeruk diekstraksi menggunakan metode CTAB dan DNA CLas diamplifikasi menggunakan polymerase chain reaction (PCR) dengan pasangan primer A2/J5. Hasil amplifikasi menunjukkan bahwa infeksi huanglongbing dideteksi positif dari daun jeruk dari Bogor dan Cibodas (Jawa Barat), Tuban dan Jember (Jawa Timur), serta Katung, Bayung Gede, Kerta, dan Pancasari (Bali). Penyejajaran urutan nukleotida contoh yang terdeteksi positif menunjukkan tingkat kemiripan yang tinggi pada daerah ribosomal protein $\beta$-operon dengan CLas OK901 asal Okinawa (Jepang). Isolat CLas asal Bogor, Cibodas, Tuban, Jember, dan Katung diketahui identik dengan isolat $C$ Las asal Indonesia yang telah dilaporkan sebelumnya. Isolat CLas asal Bayung Gede, Pancasari, dan Kerta memiliki perbedaan urutan nukleotida pada 6 titik basa dari total 539 basa yang dibandingkan dengan daerah konservatifnya, namun hanya 3 titik basa yang dapat memengaruhi asam amino yang dihasilkan.
\end{abstract}

Kata kunci: citrus vein phloem degeneration, homologi, perubahan basa tunggal

\begin{abstract}
Huanglongbing also known in Indonesia as citrus vein phloem degeneration (CVPD) is a devastating disease in citrus plantation worldwide, especially in Asia, Africa, and America. In Asian countries including Indonesia, Candidatus Liberibacter asiaticus (CLas) has been confirmed as the causal agent of huanglongbing disease on citrus. Distribution of CLas in Indonesia has been reported in West Borneo, East Nusa Tenggara, Bali, Yogyakarta, Central Java and East Java. The purpose of this study was to detect CLas in several Indonesia's citrus plantations that has not and has been reported previously and to study its genetic diversity and their relationship. DNA of plant samples, i.e. citrus leaves, was extracted using CTAB method and CLas was amplified using PCR with the A2/J5 primer pair. DNA amplification results showed that infection of $C$ Las was positively detected from samples from Bogor and Cibodas (West Java), Tuban and Jember (East Java), as well as Katung, Bayung Gede, Kerta, and Pancasari (Bali). Alignment of nucleotide sequences from positive samples showed that their ribosomal protein
\end{abstract}

*Alamat penulis korespondensi: Departemen Proteksi Tanaman, Fakultas Pertanian, Institut Pertanian Bogor. Jalan Kamper, Kampus Dramaga IPB, Bogor 16680

Tel: 0251-8629364, Faks: 0251-8629362, Surel: kmutaqin@gmail.com 
$\beta$-operon has high similiarity to that of $C$ Las OK901 originated from Okinawa (Japan). Isolates of $C$ Las originated from Bogor, Cibodas, Tuban, Jember, and Katung have been known to be identical to other $C$ Las of Indonesian origins reported earlier. Isolates of CLas originated from Bayung Gede, Pancasari, and Kerta have single nucleotide polymorphisms at 6 points of bases of the 539 total bases compared in their conservative regions, although only 3 of the 6 bases could affect their amino acid sequences.

Key words: citrus vein phloem degeneration, homology, single nucleotide polymorphism.

\section{PENDAHULUAN}

Huanglongbing atau di Indonesia dikenal sebagai citrus vein phloem degeneration (CVPD) adalah penyakit tanaman jeruk paling merusak pada jeruk di benua Asia, Afrika, dan Amerika. Penyakit ini awalnya diduga karena keracunan mineral atau kekurangan hara. Penelitian tentang huanglongbing mulai dilakukan ketika penyakit dilaporkan menyebabkan penurunan produksi yang besar dan semakin meluas serangannya (Bove 2006). Infeksi penyakit huanglongbing pada tanaman jeruk di Indonesia dilaporkan mencapai $62.34 \%$ di Jawa Timur, 60\% di Bali Utara, dan $70 \%$ di Sulawesi Tenggara. Di Kalimantan Barat kerugian karena penyakit ini mencapai Rp. 120 milyar per tahun (Nurhadi 2015).

Penyebab penyakit huanglongbing pada tanaman jeruk dilaporkan disebabkan oleh tiga spesies berbeda, yaitu Candidatus Liberibacter asiaticus (CLas) yang tersebar di benua Asia, Candidatus Liberibacter africanus (CLaf) yang tersebar di benua Afrika (Jagoueix et al. 1996), dan Candidatus Liberibacter americanus (CLam) yang tersebar di benua Amerika (Teixeira et al. 2005). Di Indonesia penyebab penyakit huanglongbing telah dikonfirmasi sebagai CLas (Jagoueix et al. 1996) yang tersebar di Sambas (Kalimantan Barat), Kupang (Nusa Tenggara Timur), Buleleng dan Kintamani (Bali), Sleman (Yogyakarta), Purwokerto (Jawa Tengah), dan Jawa Timur (Tomimura et al. 2009).

Deteksi CLas dapat dilakukan dengan metode konvensional, menggunakan medium selektif Liber A, tetapi isolat yang dihasilkan belum memberikan informasi yang cukup untuk mengungkap hubungan kekerabatan dan keragaman genetika (Sechler et al. 2009). Penggunaan metode polymerase chain reaction (PCR) untuk deteksi secara molekuler tetap dibutuhkan karena produk PCR berupa amplikon DNA dapat digunakan dalam proses perunutan nukleotida $C$ Las isolat Indonesia. Dengan demikian, keragaman genetika antarisolat yang diteliti maupun dengan isolat lain yang telah dilaporkan pada pangkalan data gen dapat dibandingkan. Tujuan penelitian ini ialah mendeteksi CLas sebagai penyebab penyakit huanglongbing pada beberapa lokasi pertanaman jeruk di Indonesia yang belum dan telah dilaporkan sebelumnya serta mengevaluasi kekerabatan dan keragaman genetika CLas isolat Indonesia.

\section{BAHAN DAN METODE}

\section{Pengambilan Contoh Bagian Tanaman Jeruk}

Contoh bagian tanaman yang digunakan ialah helai daun tanaman jeruk (Citrus reticulata syn. nobilis) dengan gejala khas infeksi huanglongbing, yaitu klorosis dengan tulang daun tetap berwarna hijau. Lokasi pengambilan contoh ialah pertanaman jeruk di Bogor, Cisurupan, Cianjur dan Cibodas (Jawa Barat); Kebumen (Jawa Tengah); Jember dan Tuban (Jawa Timur); Katung Kintamani, Bayung Gede Kintamani, Kerta Payangan, dan Pancasari Buleleng (Bali); serta Pontianak (Kalimantan Barat). Helai daun jeruk dimasukkan ke dalam kantong plastik dan disimpan dalam lemari pendingin bersuhu $-80{ }^{\circ} \mathrm{C}$ hingga dilakukan ekstraksi DNA total.

\section{Ekstraksi DNA Total Contoh Daun Jeruk}

Ekstraksi DNA total dilakukan berdasarkan metode Gopal et al. (2007). Sebanyak $0.1 \mathrm{~g}$ tulang daun digerus dengan $500 \mu \mathrm{L}$ bufer ekstraksi (50 mM Tris- $\mathrm{HCl} \mathrm{pH} 8,0.7 \mathrm{M} \mathrm{NaCl}$, $10 \mathrm{mM}$ EDTA, $1 \%$ CTAB, dan $1 \%$ ß-merkaptoetanol). Proses lisis menggunakan 
penangas air pada suhu $60^{\circ} \mathrm{C}$ selama 120 menit, sedangkan untuk mengeliminasi kontaminan yang merusak kualitas DNA menggunakan $500 \mu \mathrm{L}$ kloroform:isoamilalkohol (24:1). Proses presipitasi DNA menggunakan natrium asetat $3 \mathrm{M}$ (pH 5.2) sebanyak 1:10, supernatan dan isopropanol sebanyak $2: 3$, kemudian diinkubasi semalam pada suhu $20{ }^{\circ} \mathrm{C}$. Pelet DNA yang terbentuk dicuci dengan $500 \mu \mathrm{L}$ etanol $80 \%$ lalu diresuspensi menggunakan 30-100 $\mu \mathrm{L}$ Tris-EDTA bergantung pada ketebalan pelet DNA yang dihasilkan.

\section{Amplifikasi Gen Ribosomal Protein $\beta$-Operon $C$ Las}

DNA total hasil ekstraksi diamplifikasi dengan PCR menggunakan sepasang oligonukleotida yang spesifik pada daerah ribosomal protein $\beta$-operon CLas yaitu forward A2(5'TATAAAGGTTGACCTTTCGAGTTT-'3) yang dirancang dari gen rplA pada posisi 869-892 dari total $2.6 \mathrm{kpb}$ nukleotida $\beta$-operon dan reverse J5(5'CAAAAGCAGAAATAGCACGAACAA-3') yang dirancang dari gen rplJ pada posisi 1547-1571 dari total $2.6 \mathrm{kpb}$ nukleotida $\beta$-operon (Hocquellet et al. 1999). Komposisi bahan yang digunakan ialah $12.5 \mu \mathrm{L} 2 \mathrm{x}$ Go Taq ${ }^{\circledR G}$ Green Master mix (Promega), $1 \mu \mathrm{L}$ primer forward $20 \mu \mathrm{M}, 1 \mu \mathrm{L}$ primer reverse $20 \mu \mathrm{M}, 1 \mu \mathrm{L}$ templat DNA, dan $9.5 \mu \mathrm{L}$ air bebas nuklease sehingga volume menjadi $25 \mu \mathrm{L}$. Amplifikasi dilakukan menggunakan mesin thermal cycler (PCR Gene AMP PCR System 9700) dengan program pradenaturasi pada suhu $94{ }^{\circ} \mathrm{C}$ selama 3 menit, 35 siklus meliputi denaturasi $92{ }^{\circ} \mathrm{C}$ selama 45 detik, aneling $62{ }^{\circ} \mathrm{C}$ selama 45 detik, dan ekstensi $72{ }^{\circ} \mathrm{C}$ selama 90 detik, serta ekstensi suhu $72^{\circ} \mathrm{C}$ selama 5 menit.

\section{Analisis Perunutan Nukleotida dan Keragaman Genetika $C$ Las}

Hasil perunutan DNA CLas yang dilakukan di First Base Malaysia dianalisis menggunakan program basic local alignment search tool (BLAST) dengan program optimasi untuk mendapatkan urutan basa
DNA CLas pembanding asal Indonesia yang telah dilaporkan dalam situs national center for biotechnology information (NCBI). Runutan nukleotida yang diperoleh dianalisis menggunakan penyejajaran berganda ClustalW pada perangkat lunak Bioedit sequence alignment editor versi 7.1.3. Hubungan kekerabatan antarisolat dan analisis keragaman genetika dikonstruksi menggunakan perangkat lunak molecular evolutionery genetic analysis (MEGA 6.06) dengan bootstrap 1000 kali ulangan.

\section{HASIL}

\section{Deteksi CLas Menggunakan PCR dengan Primer A2/J5}

Amplifikasi DNA Clas pada daerah ribosomal protein $\beta$-operon menggunakan primer A2/J5 dari total 48 contoh DNA yang berasal dari daun jeruk bergejala huanglongbing di Indonesia menunjukkan 32 contoh DNA terdeteksi positif dan 16 contoh DNA terdeteksi negatif. DNA CLas terdeteksi pada 8 lokasi pengambilan contoh dengan ulangan masing-masing berjumlah 4 contoh, yaitu Bogor dan Cibodas, Tuban dan Jember, Katung Kintamani, Bayung Gede Kintamani, Kerta dan Pancasari Buleleng yang ditandai dengan terbentuknya pita DNA dengan ukuran \pm 703 pb. Pada contoh yang berasal dari 4 lokasi lainnya beserta ulangan yang masingmasing berjumlah 4 contoh DNA Cisurupan dan Cianjur (Jawa Barat), Kebumen (Jawa Tengah) dan Pontianak (Kalimantan Barat), tidak terdeteksi adanya DNA CLas (Gambar 1, 2, dan 3).

\section{Analisis Hubungan Kekerabatan dan Keragaman Genetika $C$ Las Isolat Indonesia Berdasarkan Urutan DNA Gen Ribosomal Protein $\beta$-operon}

Hasil penyejajaran urutan DNA contoh yang terdeteksi positif huanglongbing di Indonesia dengan berbagai urutan DNA yang terdapat pada pangkalan data GenBank menunjukkan bahwa contoh DNA asal Bogor, Cibodas, Tuban, Jember, Katung, Bayung 


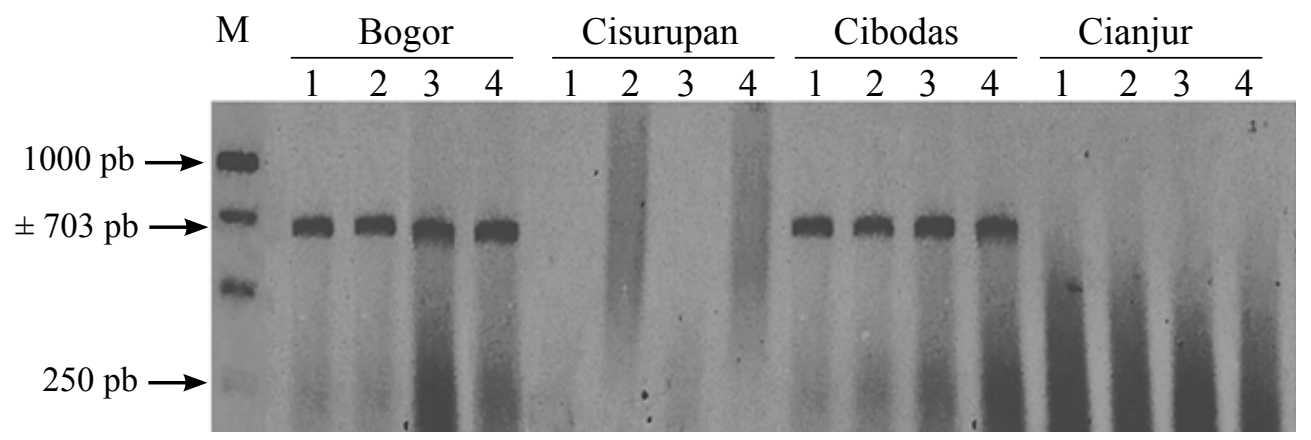

Gambar 1 Visualisasi fragmen DNA CLas asal Jawa Barat hasil amplifikasi PCR dengan primer A2/J5 pada gel agarosa 1\%. (M: penanda $1 \mathrm{Kpb}$ Thermo Scientific, 1-4: replikasi penelitian)

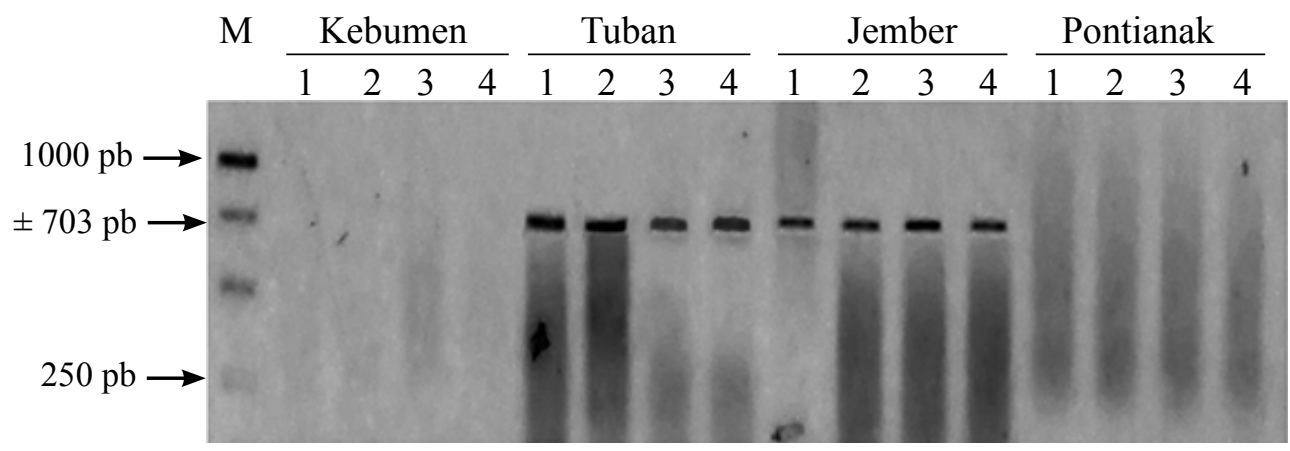

Gambar 2 Visualisasi fragmen DNA CLas asal Jawa Tengah (Kebumen), Jawa Timur (Tuban dan Jember) dan Kalimantan Barat (Pontianak) hasil amplifikasi PCR dengan primer A2/J5 pada gel agarosa 1\%. (M: penanda $1 \mathrm{Kpb}$ Thermo Scientific, 1-4: replikasi penelitian)

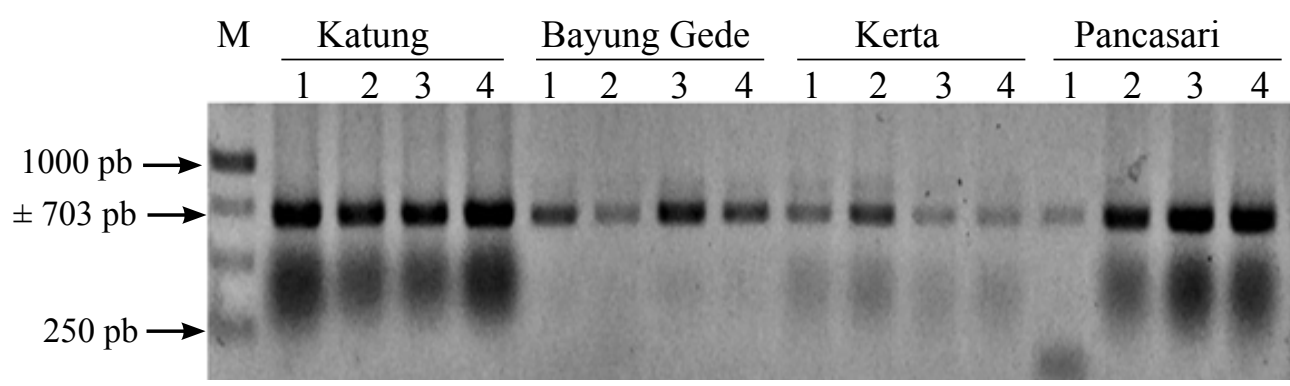

Gambar 3 Visualisasi fragmen DNA CLas asal Bali hasil amplifikasi PCR dengan primer A2/ J5 pada gel agarosa 1\%. (M: penanda $1 \mathrm{Kpb}$ Thermo Scientific, 1-4: replikasi penelitian)

Gede, Kerta dan Pancasari memiliki kemiripan dengan CLas asal Texas (USA), Guangdong (Cina), Hormozgan (Iran), Yogyakarta (Indonesia), Okinawa (Jepang), Taiwan, dan Pradesh (India) dengan tingkat kemiripan 98-100\% serta jumlah basa yang sama dan sejajar (query cover) mencapai 80-99\%. Isolat $C$ Las asal Indonesia hasil deteksi positif pada penelitian ini juga dibandingkan dengan isolat $C$ Las asal Indonesia yang telah dilaporkan sebelumnya dan hasil pensejajarannya menunjukkan bahwa urutan nukleotida $C$ Las isolat Indonesia memiliki tingkat kemiripan yang bervariasi mulai dari $90.5 \%$ hingga identik (100\%). Isolat CLas asal Indonesia yang telah dilaporkan sebelumnya diketahui memiliki tingkat kemiripan yang saling identik pada bagian ribosomal proteinnya ditandai dengan persentase homologi $100 \%$ pada semua isolat pembanding tersebut. Isolat CLas asal Bogor (Jawa Barat) diketahui lebih mirip dengan isolat CLas asal Katung (Bali) dengan tingkat kemiripan 98.4\% dibandingkan dengan isolat lainnya bahkan dengan isolat asal Cibodas yang juga berasal dari Jawa Barat dengan tingkat kemiripan 98\%. Isolat Cibodas 
sendiri diketahui identik dengan isolat asal Jember (Jawa Timur) dengan persentase kemiripan sebesar $100 \%$. Berdasarkan tingkat kemiripannya, isolat Tuban diketahui mirip dengan isolat asal Jember yang juga berasal dari Jawa Timur dan Cibodas yang berasal dari Jawa Barat dengan persentase sebesar 99.1\%. Isolat asal Bayung Gede (Bali) diketahui memiliki tingkat kemiripan yang paling tinggi dengan isolat asal Bogor yaitu 97\%, isolat asal Pancasari (Bali) lebih mirip dengan isolat asal Katung (Bali) dengan persentase kemiripan sebesar 93\%, sedangkan isolat asal Kerta (Bali) memiliki kemiripan yang paling tinggi dengan isolat $C$ Las asal Indonesia yang telah dilaporkan sebelumnya, yaitu isolat asal Sambas, Kalimantan Barat (AY342001), Sleman, Yogyakarta (AB480147), Purworejo, Jawa Tengah (AB480149), Kupang, Nusa Tenggara Timur (AB480150), Jawa Timur (AB480158), dan Kintamani, Bali (AB480159). Isolat pembanding dari spesies dan negara asal berbeda yang digunakan dalam penelitian ini, yaitu isolat CLaf asal Afrika Selatan (JF419555) menunjukkan persentase kemiripan yang kecil dengan semua isolat Clas, yaitu $<70 \%$ (Tabel 1).

Analisis filogenetika kekerabatan CLas di Indonesia menunjukkan bahwa isolat-isolat tersebut terbagi menjadi 4 gugus (cluster) berbeda dengan isolat CLas asal Indonesia yang telah dilaporkan sebelumnya terletak pada gugus yang sama. Isolat $C$ Las asal Bogor dan Cibodas (Jawa Barat), Tuban dan Jember (Jawa Timur) serta Katung (Bali) diketahui berada dalam 1 gugus dengan isolat CLas pembanding asal Indonesia yang menandakan bahwa isolat tersebut memiliki kekerabatan yang sangat erat dan memiliki keragaman yang sangat rendah secara genetika. Berbeda dengan isolat $C$ Las asal Indonesia lainnya, isolat asal Bayung Gede (Bali), Kerta (Bali) dan Pancasari (Bali) masing-masing berada pada gugus yang berbeda. Isolat asal Bayung Gede memiliki kekerabatan yang lebih erat dengan gugus $C$ Las asal Indonesia yang telah dilaporkan sebelumnya dengan koefisien jarak genetika $<0.01$ dibandingkan dengan isolat asal Kerta dengan koefisien jarak genetika mendekati
0.01 dan isolat asal Pancasari dengan koefisien jarak genetika $>0.02$. Meskipun isolat $C$ Las asal Indonesia terbagi ke dalam beberapa gugus, perbedaan koefisien jarak genetikanya tergolong rendah jika dibandingkan dengan spesies lainnya yang digunakan sebagai pembanding, yaitu Claf dengan koefisien jarak genetika mencapai $>0.12$ (Gambar 4).

Perbedaan gugus pada isolat CLas asal Indonesia menunjukkan adanya keragaman genetika pada isolat-isolat tersebut. Keragaman genetika dalam komunitas pada spesies yang sama pada umumnya ditandai dengan perubahan basa tunggal pada nukleotida isolat tersebut. Pada penelitian ini ditemukan beberapa perubahan basa tunggal yang terdapat pada 3 isolat asal Bali, yaitu isolat Bayung Gede, Kerta, dan Pancasari, sedangkan pada isolat lainnya tidak ditemukan adanya perubahan. Perubahan basa tunggal terjadi pada 6 titik basa dari 587 basa ukuran nukleotida yang sama dan sejajar pada daerah gen rpLA dan rpLJ ribosomal protein $\beta$-operon Clas, yaitu basa ke-509, 519, 552, 567, 571, 580, dan 586. Isolat $C$ Las asal Kerta menunjukkan perubahan basa tunggal yang terjadi pada 2 titik, yaitu pada basa ke-509 dan 567, sedangkan isolat $C$ Las asal Bayung Gede dan Pancasari terjadi pada 4 titik, yaitu pada basa ke-519, 552, 571, 580 dan 586. Pada basa ke-509, komunitas $C$ Las asal Indonesia menunjukkan basa adenina (A), tetapi pada isolat Kerta berubah menjadi timina (T). Pada basa ke-519, isolat asal Bayung Gede dan Pancasari masing-masing mengalami perubahan menjadi basa sitosina (C) dan $\mathrm{T}$ sedangkan pada isolat CLas lainnya menunjukkan basa A. Pada basa ke-552, basa pada isolat $C$ Las menunjukkan $\mathrm{A}$, tetapi pada isolat Bayung Gede dan Pancasari berubah menjadi guanina $(\mathrm{G})$ dan T. Pada basa ke-567, semua isolat $C$ Las asal Indonesia menunjukkan basa A tetapi pada isolat Kerta menunjukkan basa T. Selanjutnya isolat asal Bayung Gede dan Pancasari pada basa ke-571 menunjukkan perubahan dari basa $\mathrm{G}$ menjadi basa $T$ sedangkan pada basa ke-580 perubahan yang terjadi ialah dari basa A menjadi basa $\mathrm{C}$ dan $\mathrm{T}$ (Tabel 2). Perubahan basa tunggal 


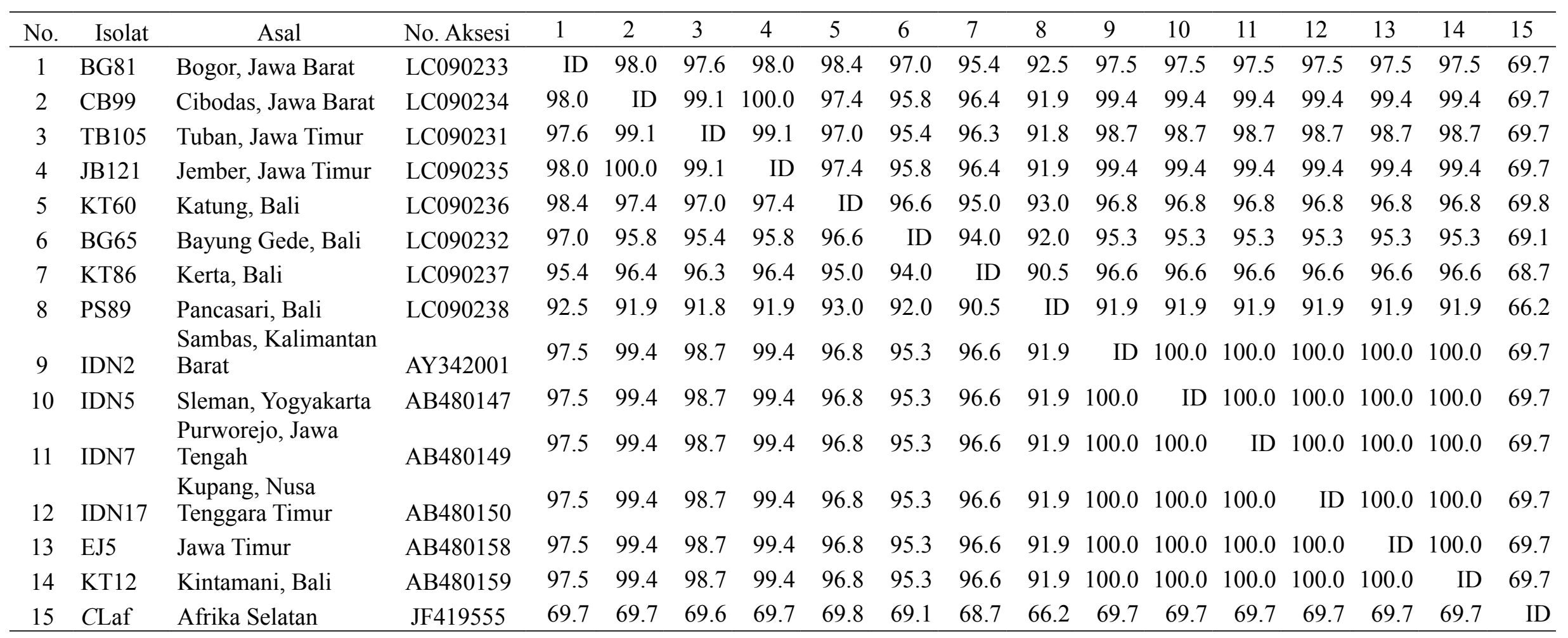


yang terjadi di dalam komunitas CLas asal Indonesia tidak semuanya memengaruhi asam amino yang dihasilkan berdasarkan proses simulasi translasi pada program MEGA 6.06. Perubahan basa ke-509 pada isolat Kerta menjadi basa $\mathrm{T}$ diketahui mengubah asam amino yang dihasilkan dari lisina $(\mathrm{K})$ menjadi metionina (M). Pada perubahan basa ke-571, yaitu dari $\mathrm{G}$ menjadi $\mathrm{T}$ di isolat Bayung Gede dan Pancasari diketahui mengubah asam amino valina (V) menjadi leusina (L), sedangkan perubahan basa ke-580 pada isolat Bayung Gede menghasilkan asam amino histidina $(\mathrm{H})$ dan isolat Pancasari menghasilkan asam amino

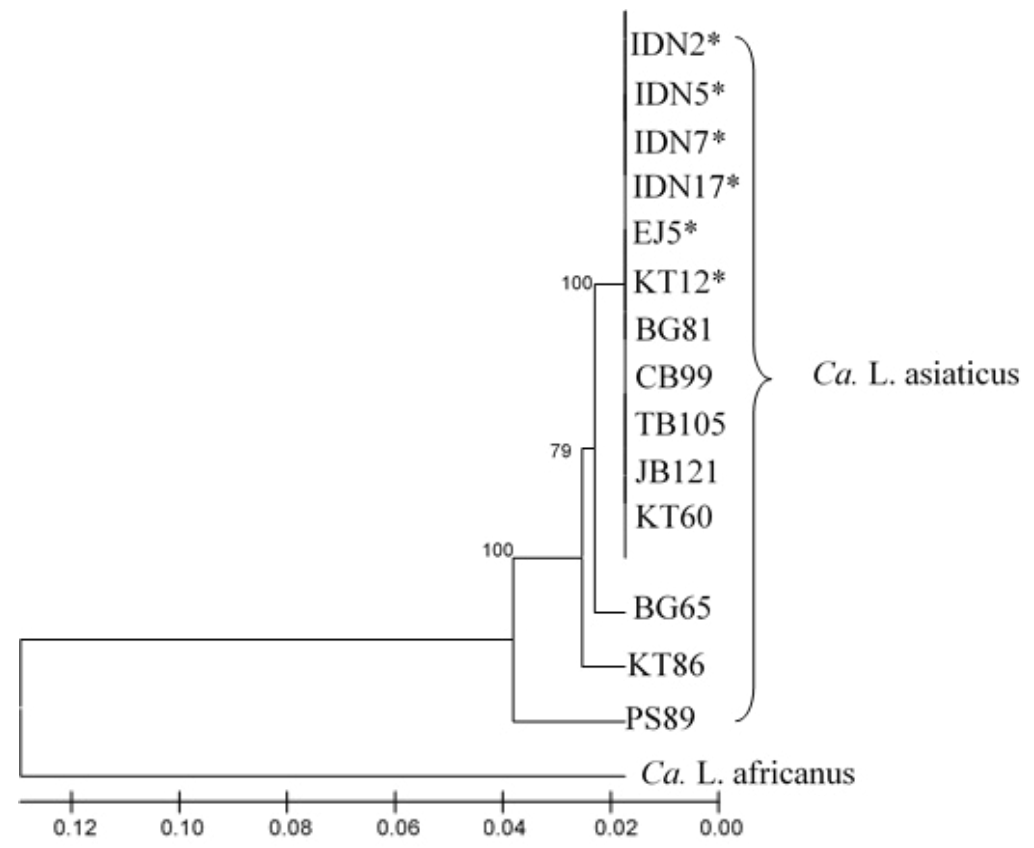

Gambar 4 Filogenetika kekerabatan Candidatus Liberibacter asiaticus isolat Indonesia menggunakan program MEGA 6.06 dengan metode UPGMA.

*isolat $C$ Las asal Indonesia yang digunakan sebagai pembanding

Tabel 2 Perubahan basa tunggal pada komunitas isolat Candidatus Liberibacter asiaticus asal Indonesia.

\begin{tabular}{|c|c|c|c|c|c|c|c|c|c|c|c|}
\hline \multirow{2}{*}{ Isolat } & \multirow{2}{*}{ Asal } & \multicolumn{10}{|c|}{ Urutan basa dalam nukleotida } \\
\hline & & 1 & 2 & 509 & 519 & 552 & 567 & 571 & 580 & 586 & 587 \\
\hline BG81 & Bogor, Jawa Barat & $\mathrm{G}$ & $\mathrm{T}$ & $\mathrm{A}$ & $\mathrm{A}$ & $\mathrm{A}$ & $\mathrm{A}$ & $\mathrm{G}$ & $\mathrm{A}$ & A & $\mathrm{T}$ \\
\hline CB99 & Cibodas, Jawa Barat & $\mathrm{G}$ & $\mathrm{T}$ & A & A & A & A & $\mathrm{G}$ & A & A & $\mathrm{T}$ \\
\hline TB105 & Tuban, Jawa Timur & $\mathrm{G}$ & $\mathrm{T}$ & A & A & A & A & $\mathrm{G}$ & A & A & $\mathrm{T}$ \\
\hline JB121 & Jember, Jawa Timur & $\mathrm{G}$ & $\mathrm{T}$ & A & A & A & A & G & A & A & $\mathrm{T}$ \\
\hline KT60 & Katung, Bali & $\mathrm{G}$ & $\mathrm{T}$ & A & A & A & A & $\mathrm{G}$ & A & A & $\mathrm{T}$ \\
\hline BG65 & Bayung Gede, Bali & $\mathrm{G}$ & $\mathrm{T}$ & A & $\mathrm{C}$ & G & A & $\mathrm{T}$ & $\mathrm{C}$ & A & $\mathrm{T}$ \\
\hline KT86 & Kerta, Bali & G & $\mathrm{T}$ & $\mathrm{T}$ & A & A & $\mathrm{T}$ & G & A & A & $\mathrm{T}$ \\
\hline PS89 & Pancasari, Bali & $\mathrm{G}$ & $\mathrm{T}$ & A & $\mathrm{T}$ & $\mathrm{T}$ & A & $\mathrm{T}$ & $\mathrm{T}$ & A & $\mathrm{T}$ \\
\hline IDN2 & $\begin{array}{l}\text { Sambas, Kalimantan } \\
\text { Barat }\end{array}$ & G & $\mathrm{T}$ & A & A & A & A & G & A & A & $\mathrm{T}$ \\
\hline IDN5 & Sleman, Yogyakarta & $\mathrm{G}$ & $\mathrm{T}$ & A & A & A & A & G & A & A & $\mathrm{T}$ \\
\hline IDN7 & Purworejo, Jawa Tengah & G & $\mathrm{T}$ & A & A & A & A & G & A & A & $\mathrm{T}$ \\
\hline IDN17 & $\begin{array}{l}\text { Kupang, Nusa Tenggara } \\
\text { Timur }\end{array}$ & G & $\mathrm{T}$ & A & A & A & A & G & A & A & $\mathrm{T}$ \\
\hline EJ5 & Jawa Timur & G & $\mathrm{T}$ & A & A & A & A & G & A & A & $\mathrm{T}$ \\
\hline KT12 & Kintamani, Bali & $\mathrm{G}$ & $\mathrm{T}$ & A & A & A & A & $\mathrm{G}$ & A & A & $\mathrm{T}$ \\
\hline
\end{tabular}


tirosina $(\mathrm{Y})$ dengan a(N) sebagai asam amino yang dihasilkan oleh isolat CLas pembanding asal Indonesia lainnya.

\section{PEMBAHASAN}

Pasangan primer A2/J5 untuk amplifikasi DNA CLas yang digunakan dalam penelitian ini diketahui menghasilkan pita DNA yang lebih tebal dan konsisten dibandingkan dengan primer yang dirancang berdasarkan 16S DNA walaupun memiliki tingkat sensitivitas yang sama (Ruangwong dan Akarapisan 2006). Hal tersebut dikarenakan DNA target menggunakan primer A2/J5 lebih kecil daripada primer yang dirancang dari 16S DNA sehingga degradasi DNA pada saat amplifikasi dan elektroforesis dapat berkurang (Hocquellet et al. 1999). Visualisasi DNA amplikon juga menunjukkan bahwa Kerta replikasi 3 dan 4 serta Pancasari replikasi 1 memiliki ketebalan paling tipis dibandingkan dengan DNA amplikon dari lokasi lainnya walaupun menggunakan primer yang sama, yaitu A2/J5. Ketebalan DNA amplikon tersebut dipengaruhi oleh oligosakarida maupun sisa bahan ekstraksi seperti EDTA, $\mathrm{NaCl}$, dan residu etanol yang terbawa bersama suspensi DNA templat. Oligosakarida dapat membentuk ikatan yang kompleks dengan DNA templat sehingga jumlah DNA yang teramplifikasi akan berkurang, sedangkan sisa bahan ekstraksi dapat menghambat penempelan primer. Proses amplifikasi yang tidak sempurna juga dapat mengakibatkan terbentuknya smear selain disebabkan oleh faktor lain, yaitu RNA dan kontaminan lain seperti protein, lipid, dan sisa bahan kimia yang digunakan pada proses ekstraksi. Selain itu, hasil deteksi negatif dalam penelitian ini diduga disebabkan oleh distribusi CLas yang tidak merata pada jaringan tanaman dan tidak semua daun yang bergejala dalam 1 cabang menunjukkan hasil deteksi yang positif karena mobilitasnya yang mengikuti jalur translokasi fotosintat sehingga menghasilkan titer yang sangat rendah pada daun contoh (Hung et al. 1999; Li et al. 2008). Titer yang sangat rendah juga dapat menyebabkan deteksi negatif palsu pada metode PCR konvensional dan persentase deteksi negatif palsu tersebut dapat menjadi menurun dengan menggunakan metode real-time quantitative PCR (MorenoEnriquez 2014).

Penyejajaran 8 urutan nukleotida pada sebagian daerah gen ribosomal protein $\beta$-operon pada $C$ Las isolat Indonesia diketahui juga memberikan hasil yang sama dengan urutan nukleotida yang diamplifikasi pada daerah 16S rRNA, yaitu memiliki tingkat kemiripan yang tinggi dengan CLas isolat Okinawa, Jepang (Subandiyah et al. 2000). Hal tersebut menunjukkan bahwa amplifikasi DNA CLas pada dua daerah amplifikasi tersebut dapat memberikan hasil yang sama. Hasil penyejajaran tersebut juga menunjukkan bahwa CLas asal Indonesia memiliki kekerabatan yang lebih erat dengan CLas asal Okinawa dibanding CLas asal Poona (India) yang merupakan 2 kelompok besar CLas di Asia (Adkar-Purushothama et al. 2009). Pada penyejajaran CLas isolat Indonesia yang ditemukan dalam penelitian ini dengan CLas isolat Indonesia yang telah dilaporkan sebelumnya terlihat adanya keragaman genetika yang ditandai dengan tingkat kesamaan gen ribosomal protein $\beta$-operon yang bervariasi mulai dari $91.9 \%$ hingga $100 \%$. Selain itu, filogenetika kekerabatan $C$ Las di Indonesia juga menunjukkan adanya 4 gugus berbeda pada pohon filogenetika tersebut. Pohon filogenetika tersebut tetap menunjukkan urutan nukleotida yang dibandingkan dengan Clas, walaupun terbagi menjadi 4 gugus karena koefisien jarak genetikanya tergolong kecil, yaitu $<0.02$ dibandingkan dengan spesies terdekat lain yang digunakan sebagai pembanding, yaitu $C$ Laf dengan jarak genetika $>0.12$. Keragaman genetika pada CLas asal Bogor dan Cibodas, Purwokerto, Sleman, Tuban, Jember, Katung Kintamani, Buleleng, Sambas, dan Kupang berasal dari daerah variatif gen ribosomal protein $\beta$-operon $C$ Las tersebut dikarenakan isolat tersebut berada dalam gugus yang sama pada pohon filogenetika, sedangkan isolat asal Bayung Gede, Kerta, dan Pancasari berasal dari daerah konservatifnya sehingga masing- 
masing memiliki gugus tersendiri. Perbedaan gugus pada suatu spesies yang sama disebabkan oleh adanya mutasi basa tunggal yang terjadi pada daerah konservatif isolat-isolat yang dibandingkan (Moreno-Enriquez 2014).

Metode analisis mutasi basa tunggal (single nucleotide polymorpism) pada program MEGA 6.06 digunakan untuk menganalisis keragaman genetika gen ribosomal protein $\beta$-operon pada $C$ Las asal Indonesia baik yang sudah ataupun sedang dilaporkan pada pangkalan data GenBank dengan melihat perbedaan basa secara visual. Analisis mutasi basa tunggal $C$ Las isolat Indonesia dilakukan pada daerah konservatif gen ribosomal protein $\beta$-operon yang berukuran sama dan sejajar pada semua isolat yang dibandingkan. Daerah konservatif digunakan untuk meningkatkan tingkat kepercayaan bahwa basa tunggal yang termutasi bukan merupakan kesalahan dalam proses perunutan nukleotida (Quaglino et al. 2009). Dalam penelitian ini diketahui terdapat 6 basa tunggal yang termutasi, yaitu pada isolat Bayung Gede, Kerta dan Pancasari. Isolat lainnya menunjukkan urutan basa yang sama persis, dan 533 basa lainnya pada daerah konservatif yang dibandingkan juga menunjukkan urutan basa yang sama. Namun, dari 6 basa tunggal yang termutasi diketahui bahwa hanya 3 basa tunggal yang menyebabkan perubahan asam amino yang terbentuk berdasarkan pada simulasi pada program MEGA 6.06. Perubahan asam amino yang terbentuk adalah leusina, histidina, dan tirosina sehingga menambah jumlah asam amino tersebut dalam polipeptida yang dihasilkan oleh isolat yang bermutasi. Peranan dari asam amino leusina dan histidina ialah sebagai penyusun antibiotik dan senyawa kimia yang dilepaskan oleh sistem imun, dan tirosina sebagai penyusun bahan kimia yang dihasilkan akibat depresi (Meister 1965). Berdasarkan pada peranan asam aminonya, diduga mutasi basa tunggal yang terjadi pada isolat Bayung Gede, Kerta, dan Pancasari disebabkan oleh penggunaan tanaman jeruk transgenik yang resisten terhadap penyakit huanglongbing, seperti penggunaan bibit jeruk siem yang dimutasi dengan isotop cobalt dan penggunaan bibit yang dilekatkan pada gen CVPD $^{r}$ (resisten terhadap CLas) maupun penggunaan antibiotik dan bakterisida secara berkesinambungan. Pemakaian tetrasiklin akan menghambat perkembangan $C$ Las pada jaringan tanaman jeruk.

Penelitian ini menunjukkan bahwa pertanaman jeruk di Bogor dan Cibodas (Jawa Barat), Tuban dan Jember (Jawa Timur), serta Katung, Bayung Gede, Kerta, dan Pancasari (Bali) positif terinfeksi huanglongbing. Penyejajaran urutan nukleotida contoh DNA positif huanglongbing menunjukkan tingkat kemiripan yang tinggi pada daerah ribosomal protein $\beta$-operon terhadap $C$ Las L9 (USA), A4 (Cina), SSL (Iran), gxpsy (Cina), IDN5 (Indonesia), OK901 (Jepang), TW1 asal (Taiwan), ALD-AN (India). Isolat CLas asal Bogor, Cibodas, Tuban, Jember, dan Katung diketahui identik dengan isolat CLas asal Purwokerto (Jawa Tengah), Sleman (Yogyakarta), Jawa Timur, Buleleng dan Kintamani (Bali), Kupang (Nusa Tenggara Timur), serta Sambas (Kalimantan Barat), sedangkan isolat CLas asal Bayung Gede dan Pancasari memiliki perbedaan urutan nukleotida pada basa ke-519, 552, 571, dan 580 serta isolat CLas asal Kerta pada basa ke-509 dan 567 dari total 539 basa yang dibandingkan dengan daerah konservatif. Perubahan basa tunggal pada isolat Bayung Gede, Pancasari dan Kerta yang dapat memengaruhi perubahan asam amino yang dihasilkan ialah pada basa ke-509, 571, dan 580.

\section{UCAPAN TERIMA KASIH}

Penelitian ini didanai oleh Program Beasiswa Unggulan Direktorat Jenderal Pendidikan Tinggi tahun 2012.

\section{DAFTAR PUSTAKA}

Adkar-Purushothama CR, Quaglino F, Casati P, Rama-Nayaka JG, Bianco PA. 2009. Genetic diversity among 'Candidatus Liberibacter asiaticus' isolates based on single nucleotide polymorphisms in $16 \mathrm{~S}$ rRNA and ribosomal protein genes. Ann 
Microbiol. 59(4):681-688. DOI: https:// doi.org/10.1007/BF03179208.

Bove JM. 2006. Huanglongbing: a destructive, newly-emerging, century old disease of citrus. J Plant Phytopathol. 88(1):7-37.

Gopal K, Gopi V, Palanivel S, Sreenivasulu Y. 2007. Molecular detection of greening disease in citrus by PCR: tissue source and time detection. Ann Plant Protec Sci. 15(2):384-390.

Hocquellet A, Toorawa P, Bove JM, Garnier M. 1999. Detection and identification of the two Candidatus Liberobacter species associated with citrus huanglongbing by PCR amplification of ribosomal protein genes of the $\beta$-operon. Mol Cell Prob. 13(5):373-379. DOI: https://doi. org/10.1006/mcpr.1999.0263.

Hung TH, Wu ML, Hong-Ji S. 1999. Development of a rapid method forthe diagnosis of citrus greening disease using the polymerase chain reaction. J Phytophatol. 147(10):599-604. DOI: https://doi. org/10.1046/j.1439-0434.1999.00435.x.

Jagoueix A, Bove JM, Garnier M. 1996. PCR detection of the two 'Candidatus' liberibacter species associated with greening disease of citrus. Mol Cell Probe. 10(1):43-50. DOI: https://doi.org/10.1006/ mcpr.1996.0006.

Li W, Li D, Elizabeth T, Hartung JS, Laurene L. 2008. Optimized quantification of unculturable Candidatus Liberibacter spp. in host plants using real-time PCR. Plant Dis. 92(6):854-861. DOI: https://doi. org/10.1094/PDIS-92-6-0854.

Meister A. 1965. Biochemistry of the Amino Acids. Ed ke-2. New York (US): Academic Press Inc. Moreno-Enríquez A, Minero-García Y, Ramírez-Prado JH, Loeza-Kuk E, UcVarguez A, Moreno-Valenzuela OA. 2014. Comparative analysis of $16 \mathrm{~S}$ ribosomal RNA of 'Candidatus Liberibacter asiaticus' associated with huanglongbing disease of Persian lime and Mexican lime reveals a major haplotype with worldwide distribution. Afr J Microbiol Res. 8(30):2861-2873. DOI: https://doi. org/10.5897/AJMR2014.6706.
Nurhadi. 2015. Penyakit huanglongbing tanaman jeruk (Candidatus Liberibacter asiaticus): ancaman dan strategi pengendalian. Pengembangan Inovasi Pertanian. 8(1): 21-32.

Quaglino F, Zhao Y, Bianco PA, Wei W, Casati P, Durante G, Davis RE. 2009. New 16Sr subgroups and distinct single nucleotide polymorphism lineages among grape vine Bois noir phytoplasma populations. Ann App Biol. 154(2):279289. DOI: https://doi.org/10.1111/j.17447348.2008.00294.x.

Ruangwong O, Akarapisan A. 2006. Detection of Candidatus Liberibacter asiaticus causing citrus huanglongbing disease. J Agri Technol. 2(1):111-120.

Sechler A, Scheunzel EL, Cooke P, Donnua S, Thaveechai N, Postnikova E, Stone AL, Schneider WL, Damsteegt VD, Schaad NW. 2009. Cultivation of 'Candidatus Liberibacter asiaticus' 'Ca. L. africanus', and ' $\mathrm{Ca}$. L. americanus' Associated with huanglongbing. Phytopathol. 99(5): 480-486. DOI: https://doi.org/10.1094/ PHYTO-99-5-0480.

Subandiyah S, Iwanami T, Tsuyumu S, Ieki H. 2000. Comparison of $16 \mathrm{~S}$ rDNA and $16 \mathrm{~S} / 23 \mathrm{~S}$ intergenic region sequences among citrus greening organisms in Asia. Plant Dis. 84(1):15-18. DOI: https://doi. org/10.1094/PDIS.2000.84.1.15.

Teixeira DC, Colette S, Sandrine E, Jean LD, Paulo IC, Antonio JA, Bove JM. 2005. 'Candidatus Liberibacter americanus', associated with citrus huanglongbing (greening disease) in Sao Paulo State, Brazil. Int $\mathrm{J}$ Syst Evol Microbiol. 55(1):1857-1862. DOI: https://doi. org/10.1099/ijs.0.63677-0.

Tomimura K, Miyata S, Furuya N, Kubota K, Okuda M, Subandiyah S, Hung TH, Su HJ, Iwanami T. 2009. Evaluation of genetic diversity among 'Candidatus Liberibacter asiaticus' isolates collected in Southeast Asia. Phytopathology. 99(9):10621069. DOI: https://doi.org/10.1094/ PHYTO-99-9-1062. 